\title{
Do international standards for hygienic handrubs reflect realistic usage?
}

\author{
MAC Wilkinson ${ }^{1 *}$, C Bradley ${ }^{1}$, J Hines ${ }^{2}$, K Ormandy $^{2}$, A Fraise ${ }^{1}$ \\ From 3rd International Conference on Prevention and Infection Control (ICPIC 2015) \\ Geneva, Switzerland. 16-19 June 2015
}

\section{Introduction}

Hygienic handrubs are widely used in healthcare to reduce the probability of pathogens being spread via the hands. International standards such as EN 1500 [1] have been developed to ascertain the efficacy of handrubs claiming antimicrobial action. This standard compares a reference product $(2 \times 3 \mathrm{ml}$ applications of $60 \% \mathrm{v} / \mathrm{v}$ isopropanol (IPA) over 60 seconds) with a test product(s). However, as WHO guidelines [2] recommend that drying times are limited to 30 seconds, does the standard represent realistic usage?

\section{Objectives}

This study compares the volumes of alcohol-based hand rub (ABHR) applied with drying time, antimicrobial efficacy and user acceptability. The ABHR's studied are $60 \% \mathrm{v} / \mathrm{v}$ IPA and the two WHO - recommended handrub formulations, i.e. $80 \% \mathrm{v} / \mathrm{v}$ ethanol and $75 \% \mathrm{v} / \mathrm{v}$ IPA, both of which contain $1.45 \% \mathrm{v} / \mathrm{v}$ glycerol.

\section{Methods}

Fifteen volunteers were recruited to test six volumes of the three ABHR's, ranging from $0.5 \mathrm{ml}$ to $3 \mathrm{ml}$. The drying time and user acceptability were recorded. Five volunteers were then selected to test the same volumes in the manner of an EN 1500 test. The $\log _{10}$ reduction factor (RF) in E. coli $\mathrm{K} 12$ was calculated, in addition to whether the volunteers' hands were dry at the end of the procedure.

\section{Results}

Both RF and drying time significantly increase as the volume of ABHR increases $(p<0.05$; Friedman test). The user comments also displayed a significant relationship with volume ( $p<0.05, \xi^{2}$ test), with the majority of comments negative at $3 \mathrm{ml}$. In the EN 1500 - style test, only the two smallest volumes dried fully for all ABHR's $\left(\mathrm{p}<0.05, \xi^{2}\right.$ test).

\section{Conclusion}

EN1500 was not originally designed as a means to define product dosage; however this is increasingly becoming normal practice. Our data reinforce the need for standards to more accurately reflect the volumes of handrubs that are used in practice. One possible solution involves two - tiered standards, that test both high volume / long drying times and low volume / short drying times, thus allowing formulations to be tested against a reference product under both ideal and realistic conditions.

\section{Disclosure of interest}

None declared.

\section{Authors' details}

${ }^{1}$ Hospital Infection Research Laboratory, Queen Elizabeth Hospital Birmingham, Birmingham, UK. ${ }^{2}$ Deb Research and Development, Deb Group Ltd., Denby, UK.

Published: 16 June 2015

\section{References}

1. EN 1500:2013 Chemical disinfectants and antiseptics - Hygienic handrub Test method and requirements (phase 2/step 2). .

2. WHO Guidelines on Hand Hygiene in Health Care: World Health Organization. 2009.

\section{doi:10.1186/2047-2994-4-S1-P305}

Cite this article as: Wilkinson et al:: Do international standards for hygienic handrubs reflect realistic usage? Antimicrobial Resistance and Infection Control 2015 4(Suppl 1):P305. 